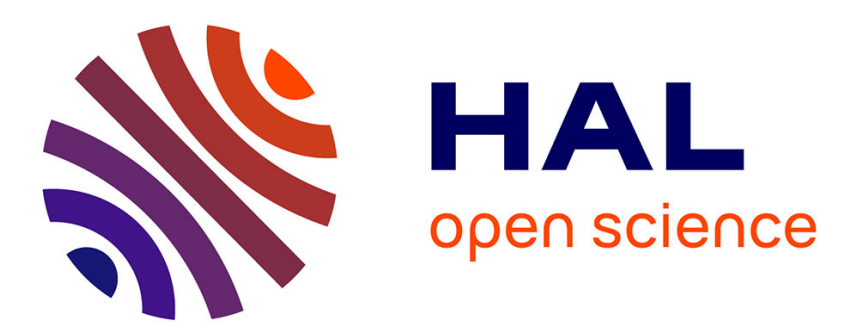

\title{
Iceberg jam floods in Icelandic proglacial rivers: testing the self-organized criticality hypothesis
}

Erwan Roussel, Jean-Pierre Toumazet, Marren Philip, Etienne Cossart

\section{To cite this version:}

Erwan Roussel, Jean-Pierre Toumazet, Marren Philip, Etienne Cossart. Iceberg jam floods in Icelandic proglacial rivers: testing the self-organized criticality hypothesis. Géomorphologie: relief, processus, environnement, 2016, 22 (1), pp.37-49. 10.4000/geomorphologie.11229 . hal-01312715

\section{HAL Id: hal-01312715 \\ https://hal.science/hal-01312715}

Submitted on 5 Nov 2019

HAL is a multi-disciplinary open access archive for the deposit and dissemination of scientific research documents, whether they are published or not. The documents may come from teaching and research institutions in France or abroad, or from public or private research centers.
L'archive ouverte pluridisciplinaire HAL, est destinée au dépôt et à la diffusion de documents scientifiques de niveau recherche, publiés ou non, émanant des établissements d'enseignement et de recherche français ou étrangers, des laboratoires publics ou privés. 


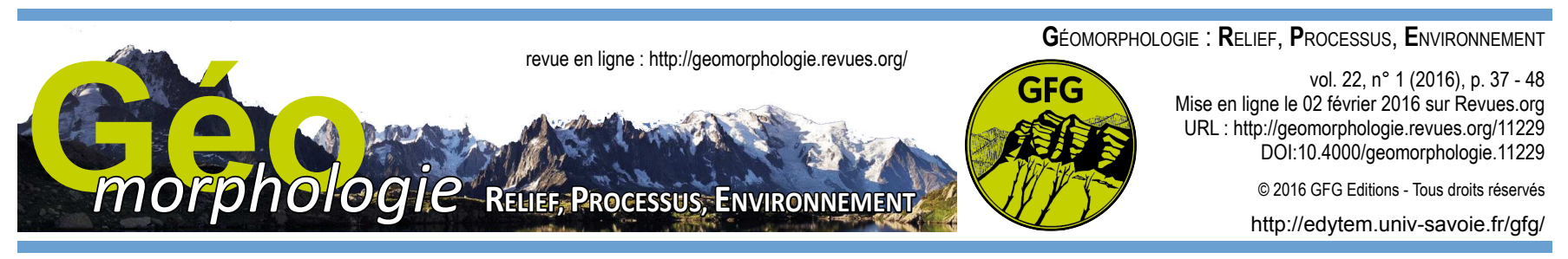

\title{
Iceberg jam floods in Icelandic proglacial rivers: testing the self-organized criticality hypothesis
}

\section{Crues de barrage glaciel dans les cours d'eau proglaciaires islandais : test de l'hypothèse de criticalité auto-organisée}

\author{
Erwan Roussel $^{\star a, b}$, Jean-Pierre Toumazet ${ }^{\mathrm{a}, \mathrm{b}}$, Philip M. Marren ${ }^{\mathrm{c}}$ \& Etienne Cossart ${ }^{\mathrm{d}, \mathrm{e}}$ \\ ${ }^{a}$ University Clermont Auvergne - University Blaise Pascal - GEOLAB, BP 10448 - F-63000 Clermont-Ferrand - France. \\ ${ }^{\mathrm{b}}$ CNRS, UMR 6042, GEOLAB - F-63057 Clermont-Ferrand - France. \\ 'Department of Geography and Development Studies - University of Chester - Chester - United Kingdom. \\ ${ }^{\mathrm{d}}$ University Paris 1 panthéon-Sorbonne - 191 rue Saint Jacques - F-75005 Paris, France. \\ ${ }^{\mathrm{e}} \mathrm{CNRS}$, UMR Prodig 8586 - 2 rue Valette - F-75005 Paris, France.
}

INFORMATION SUR LARTICLE

Reçu le 18 mai 2015

Reçu sous sa forme révisée le 21 septembre 2015 Définitivement accepté le 21 décembre 2015

*Auteur correspondant. Tél : 0473346843 Courriels :

Erwan.ROUSSEL@univ-bpclermont.fr

(E. Roussel)

J-Pierre.TOUMAZET@univ-bpclermont.fr

(J.-P. Toumazet)

p.marren@chester.ac.uk (P.M. Marren)

etienne.cossart@univ-lyon3.fr (E. Cossart)

\begin{abstract}
In this paper, we describe a fluvial marginal process associated with the formation of iceberg jams in Icelandic proglacial lakes. The floods triggered by the release of these iceberg jams have implications for the geomorphic evolution of the proglacial fluvial system. The process of iceberg jam floods share some conceptual characteristics with Self-Organized Criticality (SOC) approach of complex systems. Using a simple numerical model and field observations, we test the hypothesis that iceberg jam floods exhibit SOC. Field observations and aerial photointerpretations in southeastern Iceland demonstrate the occurrence of icebergs jam in ice-contact lakes. The mapping of the south Vatnajökull margins between 2003 and 2012 reveals an increase of the calving potentiality and a rise in the likelihood of iceberg jam flood occurrence. Based on the results of the numerical model and field observations, we suggest that iceberg jam floods should be recognized as a SOC phenomenon. Analysis of the simulated timeseries show that the iceberg jam floods become less frequent and more similar in magnitude over time. This global trend is related to the gradual enlargement of the lake outlet channel.
\end{abstract}

Keywords: proglacial rivers, proglacial lakes, iceberg jam floods, self-organized criticality, Iceland

\section{RÉSUMÉ}

Dans cet article, nous décrivons un processus fluvial associé à la formation de barrages glaciels dans les lacs proglaciaires islandais. Les crues déclenchées par la rupture de ces barrages glaciels ont des implications sur l'évolution géomorphologique des systèmes fluviaux proglaciaires. Le processus de crue de barrage glaciel partage des caractéristiques conceptuelles avec l'approche de criticalité auto-organisé (SOC) des systèmes complexes. A l'aide d'un modèle numérique simple et d'observations de terrain, nous testons l'hypothèse de criticalité auto-organisé pour les crues de barrage glaciel. Nos observations de terrain et nos travaux de photo-interprétations aériennes dans le sud de l'Islande témoignent de loccurrence de barrages glaciels dans les lacs proglaciaires islandais. Le travail de cartographie des marges sud du Vatnajökull entre 2003 et 2012 montre une augmentation de la potentialité de vêlage et une hausse de la probabilité d'occurrence des crues de barrage glaciel. Sur la base de résultats issus du modèle numérique et de nos observations de terrain, nous suggérons que les crues de barrage glaciel devraient être considérées comme un phénomène caractérisé par la criticalité auto-organisé. L'analyse des séries temporelles simulées montre que les crues de barrage glaciel deviennent moins fréquentes et d'intensité similaire au cours du temps. Cette tendance globale est liée à la calibration progressive de la géométrie du chenal à l'exutoire du lac proglaciaire.

Mots-clés : cours d'eau proglaciaires, lacs proglaciaires, crues de barrage glaciels, criticalité auto-organisée, Islande

\section{Introduction}

Proglacial rivers adjust their channel pattern and hydraulic geometry to glacier fluctuations and associated water and sediment fluxes (Maizels, 1979). Like many other glaciated regions, the retreat of Icelandic glaciers has accelerated over the last 20 years. Since 1996, Iceland largest icecap, Vatnajökull, has lost more than $2.7 \%$ of its total mass (Björnsson and Pálsson, 2008). As a result, the proglacial margin, defined as the recently deglaciated area between the glacier snout and the unconfined fluvial system beyond the Little Ice Age (LIA) moraines, has accordingly grown in size. The emergence of this complex landscape unit creates a range of storage landforms (moraines, ice-contact lakes, proglacial ponds, terraces) which affect the geomorphic coupling and the sediment connectivity from the glacier to the fluvial system (Cossart, 2014; Heckmann and Schwanghart, 2013). Notably, frontal moraines have been identified as key proglacial landforms which contribute to control the efficiency of sediment exportation (Cossart et Fort, 2008; Roussel, 2011; Cossart, 2014). Overall, the fragmented structure of the proglacial landsystem is conducive to dam effects and decreases the efficiency of sediment delivery to the fluvial system. 


\subsection{Geomorphic disconnectivity in proglacial margins: a brief state-of-art}

Marren and Toomath $(2013,2014)$ recently described rapid fluvial adjustment inside the proglacial margin due to topographic forcing related to glacial retreat. Channel confinement between moraines and the reduction in ice-proximal slope decreased the potential for braiding and forced the river to adopt a single channel. These observations imply that, in the short term, the channel pattern change observed in proglacial rivers is mainly due to topographic forcing operating within the proglacial margins. The classical drivers of channel change (hydrology and sediment supply) are only weakly significant at these short time scales in proglacial areas.

Since the pioneering work of Boulton (1986) on the incision of frontal moraines by proglacial streams, it was assumed that the transfer of sediments was mostly controlled by the frontal moraines themselves. Nevertheless the restoration of geomorphic links between the sections located upstream and downstream of the frontal moraines is complex, and affected by many threshold effects. As soon as streams are channelized across the moraines, a first negative feedback which limits the erosion of frontal moraines due to bed armouring occurs. This negative feedback has been described by Cossart and Fort (2008) and Cossart (2014). At this time, the frontal moraine may still be considered as an efficient and stable base-level. This stage lasts between 5 and 10 years minimum (Icelandic examples in Marren, 2002; Roussel, 2011), but it can last 50 or even a century in alpine examples (Cossart and Fort, 2008; Cossart, 2014). In any case, the duration of this stage is a function of the grain size of the deposits that constitute the moraine. In these upper streams, the sediment size is often beyond the competence of streams, leading to bed armouring. The incision of proglacial moraines by water is estimated between 2 and $5 \mathrm{~mm}$.yr-1 during this first stage (Cossart, 2014). Finally, the only way to break up this negative feedback is the occurrence of specific events such as low frequency but high magnitude floods or iceberg jams. In any case, the event must cause a sufficient increase in stream power to remove the armoured layer that was preventing further channel enlargement.

\subsection{Ice-contact lakes and the potential for iceberg jam floods}

In the current context of glacial retreat, the emergence of quasipersistent proglacial lakes within the proglacial margin affects the sediment supply to the fluvial system. These proglacial lakes are currently expanding in size and number, they affect several Icelandic glacier forelands (Carrivick and Tweed, 2013; Schomacker, 2010). They trap the coarsest part of the glacigenic sediment load and reduce the input of sediment to the proglacial fluvial system (Chew and Ashmore, 2001; Marren, 2002; Marren and Toomath, 2013; Carrivick and Tweed, 2013).

In addition, ice-contact lakes initiate a positive feedback between the area of a proglacial lake and the rate of glacier retreat through the initiation of calving process (Pelto and Hedlund, 2001; Carrivick and Tweed, 2013). The icebergs produced at the ice front slowly travel through the proglacial lake and accumulate at the lake outlet forming an iceberg jam. A similar process in fjord environments has been recently described by Peters et al. (2015). The formation of an iceberg jam can considerably hinder water flow and locally affects the water surface gradient. As soon as the resistance threshold of the jam is exceeded, a flood can be triggered which exports the stored water, parts of the icebergs forming the blockage and probably sediments. Iceberg jam floods thus represent an additional form of discharge variation impacting on proglacial rivers (Marren, 2005) and have the potential to produce changes similar to glacial outburst floods in rivers that otherwise would not experience these events. Iceberg jam floods associated with calving into proglacial lakes have some similarities to the ice-cliff collapse floods described by Ballantyne and McCann (1980) and Russell et al. (1995), although the presence of a proglacial lake, and the gradual accumulation of icebergs at the lake outlet contrast with the situation where icebergs collapsing directly into the river locally ponds the channel before a subsequent failure, and the timing and magnitude-frequency distribution of the two flood types may vary.

\subsection{The Self-Organized Criticality (SOC) models}

The process of iceberg jam formation and subsequent flooding share some conceptual characteristics with the Self-Organized Criticality (SOC) approach of complex systems defined by Bak et al. $(1987,1988)$. SOC can be considered as a group of formal models that describe dynamic systems which spontaneously reach a critical state that lead to the trigger of responses with a magnitude that may vary from insignificant to catastrophic (Frigg, 2003). A singular property of SOC is the inverse power law between the magnitude and frequency of the events which are triggered by the critical state (Dahr, 2006). Dynamical systems successfully modeled by the SOC approach are abundant in nature, and include earthquakes, mass movements, epidemics and forest fire (reviews available in Turcotte, 1999 and Bak, 1996). In geomorphology, the SOC modeling approach has been widely applied, notably to the following research fields: long term landscape evolution (Rinaldo et al., 1993; Rigon et al., 1994; Phillips, 1995), landslides (Hergarten and Neugebauer, 1998 ; Gomez et al., 2002), fluvial sediment transport (Coulthard and Van de Wiel, 2007; Van de Wiel and Coulthard, 2010) or riverbank erosion (Fonstad and Marcus, 2003 ; Croke et al., 2014). Recently, based on field observations and numerical simulations, it has been discovered that the iceberg calving process also exhibits SOC behavior (Åström et al., 2014). The main conclusion of this work is that even the biggest calving event should not be considered exceptional. Calving events exhibit the so-called "power-law distribution" associated with the critical regime of SOC. According to Åström et al. (2014), the largest fluctuation in calving events magnitude, including the collapse of the entire glacier front affected by calving process, can occur at any time (conforming to the powerlaw distribution) without any change in external forcing.

Croke et al. (2014) after Van de Wiel and Coulthard (2010) summarized the four necessary conditions for diagnosis of the existence of SOC: (1) non-linear temporal dynamics in the occurrence of disturbance events within the system; (2) an inverse power-law relation between the magnitude and frequency of the events; (3) the existence of a critical state of the system to which the system readjusts after a disturbance; (4) the existence of a cascading processes mechanism by which the same process can initiate both low-magnitude and high-magnitude events.

\subsection{Aim of the paper}

The aim of this paper is to describe the results of a study into the marginal process associated with iceberg jams in proglacial lakes, and the ensuing floods, and test the hypothesis that these processes exhibit characteristics associated with the concept of self-organized criticality (SOC). Proglacial lake development, iceberg jams and the resulting floods have major implications for the timing of water and sediment transfer from the glacier foreland to the fluvial system and understanding this process can contribute to a fuller explanation of channel adjustments of proglacial rivers to glacier retreat. 
Therefore, the objectives of this study are twofold: (i) to describe the process of iceberg jam formation based on field observations and aerial photo-interpretations of icebergs jam occurrence in ice-contact lakes of southeastern Iceland; (ii) to test the hypothesis that iceberg jam floods exhibit SOC. This last point is achieved using a simple numerical model and field observations to address the four SOC criteria described above.

\section{Study area}

The study area is located in the southeastern part of Iceland, around the Öræfi region of the Vatnajökull icecap (fig. 1A). This area is characterized by a subpolar oceanic environment with a mean annual precipitation of $1800 \mathrm{~mm}$ and a mean annual temperature of $4.8^{\circ} \mathrm{C}$ (Climatological data from Fagurhólsmyrí meteorological station for the period 1961-2006). The proglacial areas of eleven glaciers were investigated, all of which are in front of southern outlets of Vatnajökull. All these glaciers have retreated since the end of the LIA (Chenet et al., 2010 ; Roussel, 2011). The eleven selected proglacial margins differ in their landform assemblages and can be considered as a robust sample for testing the occurrence of iceberg jam formation and flood triggering.

\section{Methods}

\subsection{Field and photo-observation of iceberg jam formation}

Fieldwork in the proglacial areas of the southeastern part of Iceland was carried out during the summers 2005, 2006 and 2007. The outlets

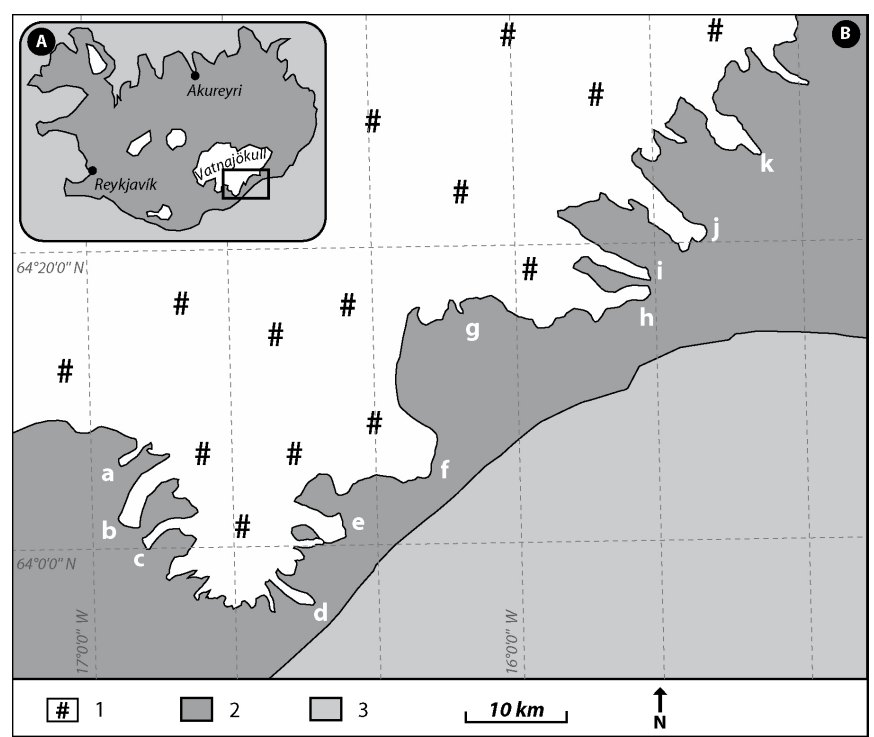

Fig. 1 - Map of the studied proglacial areas in front of the Vatnajökull glacier outlets.

A: Black box shows the location of the studied area in southeastern Iceland. B: Location map of the eleven glacier forelands which were investigated. 1: Vatnajökull icecap; 2: Proglacial areas; 3: Ocean; a: Morsárjökull; b: Skaftafellsjökull; c: Svínafellsjökull; d: Kviárjökull; e: Fjallsjökull; f: Breiðamerkurjökull; g: Brókarjökull; h: Skálafellsjökull; i: Heinabergsjökull; j: Fláajökull; k: Hoffellsjökull.

Fig. 1 - Carte des zones proglaciaires étudiées en aval des émissaires du Vatnajökull.

A : Le rectangle noir montre la localisation de la zone d'étude dans le sud-est de l'Islande. $B$ : Carte de localisation des onze zones proglaciaires investiguées. 1: Calotte du Vatnajökull ; 2 : Zones proglaciaires ; 3 : Océan ; $a$ : Morsárjökull ; $b$ : Skaftafellsjökull ; $c$ : Svínafellsjökull ; $d$ : Kvíárjökull ; $e$ : Fjallsjökull ; $f$ : Breiðamerkurjökull ; $g$ :Brókarjökull; $h$ :Skálafellsjökull; $i:$ Heinabergsjökull; $j:$ Fláajökull; $k:$ Hoffellsjökull. of ice-contact lakes were investigated in order to detect the occurrence of iceberg jam formation. Direct observations were recorded and documented with terrestrial photographs. In addition, we examined the Google Earth ${ }^{\circledR}$ imagery database, and its time-lapse tool, to extend our observation database of iceberg jam occurrence for the glaciers. The Google Earth aerial photographs displaying iceberg jams at proglacial lake outlets were recorded as indirect observations.

\subsection{Quantifying the calving potential in south-east Iceland}

Based on the photo-interpretation of 2003 aerial photographs provided by Loftmyndir ${ }^{\circledR}$ and the 2012 Google Earth $^{\circledR}$ and Landsat imagery databases, mapping with ArcGIS 10.1 software was carried out in order to quantify two main parameters: (1) the evolution between 2003 and 2012 of the area occupied by ice-contact lakes within the proglacial margins; (2) the variation between 2003 and 2012 of the length of glacier fronts with a proglacial lake interface. These two parameters were measured for the eleven proglacial margins investigated in the southern part of the Vatnajökull. These measurements provide a baseline for the evolution of the calving potential of the lakes and provide insights in the likelihood of iceberg jam formation.

\subsection{Testing for SOC using a simple numerical model}

Several SOC studies have addressed the four criteria to varying degrees. The existence of a power-law relationship between magnitude and frequency of the events is often considered as a hallmark of SOC, although this kind of relationship also exists in non-SOC systems (Phillips, 1999; Frigg, 2003). In this study, the four necessary conditions were addressed and the first two criteria were quantitatively tested using numerical simulation tools.

In order to test the non-linear temporal dynamics in the occurrence of iceberg jam floods and the existence of an inverse power-law relationship between magnitude and frequency, a simple numerical model has been built. This numerical model simulates the variation of nine parameters through time $(t)$ : the glacial meltwater discharge $\left(Q_{i n}\right)$; the iceberg height $\left(\mathrm{Ice}_{h}\right)$; the initiation of the iceberg jam (Jam), its size $\left(\mathrm{Jam}_{S}\right)$ and release $\left(\mathrm{Jam}_{R}\right)$; the water storage upstream of the iceberg jam $\left(W_{s}\right)$; the water discharge in the lake outlet $\left(Q_{o u t}\right)$; the peak discharge of iceberg jam floods $\left(Q_{r}\right)$ and the critical channel depth of the lake outlet $\left(d_{c}\right)$. In order to capture and illustrate the interactions between these parameters, the numerical model has been conceptually described through a systemic graph in figure 2 .

The glacial meltwater discharge $\left(Q_{i n}\right)$ is modeled as a sinusoidal function of time $(t)$ in hourly timesteps to take into account the diurnal oscillation of water flow in respect to melting rate variation during the day:

$$
Q_{i n}(t)=Q_{b}+\alpha\left(1+\cos \left(2 \pi f\left(t-P_{h}\right)\right)\right)
$$

Where $Q_{b}$ is the baseflow, $\alpha(\alpha>0)$ is the amplitude parameter, $f$ is the frequency of the proglacial discharge $(1 / 24), P_{h}$ is the hour of the afternoon peak flow. In this study, $Q_{b}=10 ; \alpha=1$ and $P_{h}=4$.

Iceberg production is modeled as a stochastic process with a Weibull distribution. This choice is based on the statistical results of $\mathrm{Lu}$ et al. (2013) who concluded that the iceberg size distribution $(\mathrm{N}=1085)$ is best fitted by a Weibull probabilistic law. Moreover, we assume that this distribution respects the likelihood of occurrence of the largest events (i.e. the biggest icebergs) which are able to initiate jam formation. More precisely, the height of the icebergs $\left(\right.$ Ice $\left._{h}\right)$ produced at the glacier snout is selected from a Weibull distribution. 


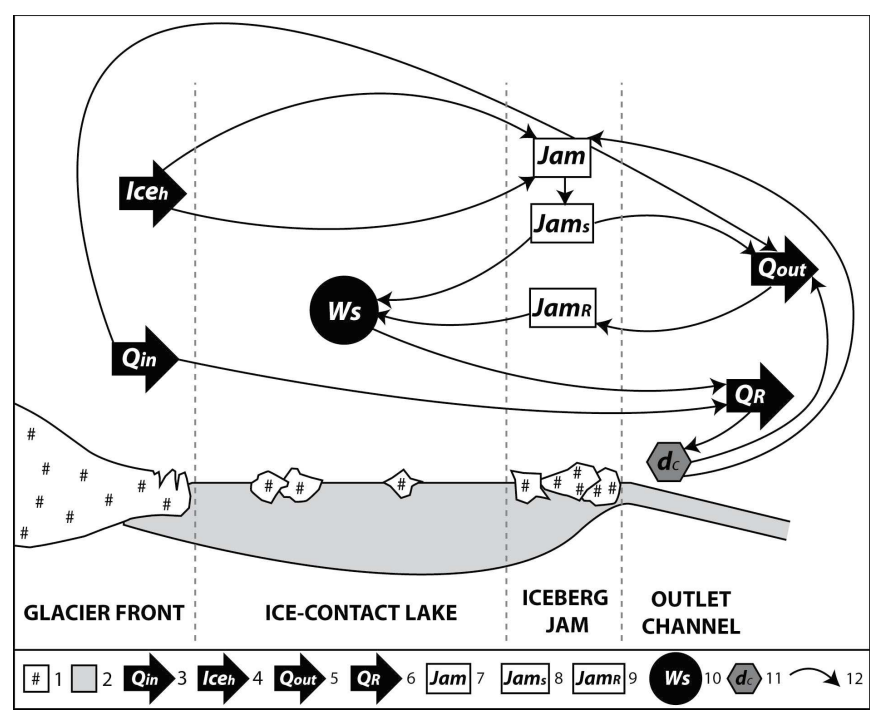

Fig. 2 - Conceptual sketch of the numerical model simulating iceberg jam flood.

Black arrows are water and icebergs fluxes; white boxes symbolizes the iceberg jamming process; black circle is the water storage due to iceberg jam; grey hexagonal symbol is the critical channel depth parameter that controls the jamming process. 1: Glacier ice and icebergs; 2 : water; 3 : the glacial meltwater discharge; 4 : the icebergs height; 5 : the water discharge in the lake outlet; 6 : the peak discharge of iceberg jam flood; 7: the initiation of the iceberg jam; 8: the iceberg jam size; 9: the iceberg jam release; 10: the water storage associated with the iceberg jam; 11: channel depth of the lake outlet; 12: control of one parameter on the other.

Fig. 2 - Schéma conceptuel du modèle numérique simulant les crues de barrage glaciel.

Les flèches noires symbolisent les flux d'eau et d'icebergs; les boites blanches symbolisent le processus de barrage glaciel; le cercle noir correspond au stockage d'eau induit par le barrage glaciel; l'hexagone gris est le paramètre de profondeur de chenal qui contrôle les processus de barrage glaciel. 1 : glace ; 2 : eau ; 3 : débit d'eau de fonte glaciaire; 4 : hauteur des icebergs ; 5 : débit à l'exutoire du lac; 6 : pic de débit des crues de barrage glaciel ; $7:$ formation d'un barrage glaciel ; $8:$ taille du barrage glaciel ; $9:$ rupture du barrage glaciel ; 10 : stockage d'eau induit par le barrage glaciel ; 11 : profondeur de chenal de l'exutoire; 12 : Contrôle d'un paramètre sur l'autre.

The probability density function of a Weibull distribution can be summarized as follows:

$$
f(x, \beta, \gamma)=\frac{\beta}{\gamma}\left(\frac{x}{\gamma}\right)^{\beta-1} e^{-\left(\frac{x}{\gamma}\right)^{\beta}}
$$

Where $\beta$ is the shape parameter and $\gamma$ is the scale parameter. In this work, $\beta=3$ and $\gamma=2$ following the results of Lu et al. (2013).

The series of iceberg heights $\left(I c e_{h}\right)$ is composed of $10^{7}$ samples: $10^{6}$ of these samples are selected from a Weibull distribution, and the $9.10^{6}$ remaining samples are set to zero. All these sample are randomly distributed, so that the probability of an iceberg occurrence for each time step is equal to $1 / 10$.

Iceberg jam initiation (Jam) is modeled as a threshold function of iceberg height $\left(\right.$ Ice $\left._{h}\right)$. We assume that a jam is built as soon as the iceberg height exceeds a critical value related to the channel depth of the lake outlet $\left(d_{c}\right)$. Taking into account the density ratio between ice and water (0.895), the critical iceberg height for jam initiation can be expressed as follow:

$$
\begin{gathered}
\operatorname{Jam}(t) \text { is set to } 1 \text { when } 0.895 \times I c e_{h}(t)>d_{c} \\
\text { it is reset to } 0 \text { after each release }
\end{gathered}
$$

The size of the jam $\left(\operatorname{Jam}_{s}\right)$ is modeled as a recursive function which sums the accumulation of iceberg heights $\left(\right.$ Ice $\left._{h}\right)$ as soon as the jam is initiated:

$$
\operatorname{Jam}_{s}(t)=\operatorname{Jam}_{s}(t-1)+\operatorname{Ice}_{h}(t) \times \operatorname{Jam}(t)
$$

The water storage $\left(W_{s}\right)$ upstream of the iceberg jam is modeled as a recursive function which sums the accumulation of water as soon as the jam is initiated:

$$
W_{s}(t)=W_{s}(t-1)+Q_{\text {in }}(t)-Q_{\text {out }}(t)
$$

The water discharge in the lake outlet $\left(Q_{\text {out }}\right)$, during the jam initiation and the jam free sequences, is modeled as:

$$
Q_{\text {out }}(t)=Q_{\text {in }}(t)\left(1-\frac{\operatorname{Jam}_{S}(t)}{I c e_{h_{\text {max }}} \times \frac{d_{c}(t)}{d_{c_{\text {init }}}}}\right)
$$

The water discharge $\left(Q_{\text {out }}\right)$ depends on the proglacial water discharge $\left(Q_{i n}\right)$ and on the jam size $\left(\operatorname{Jam}_{S}\right)$. For the first jam of the considered period, we assumed that the lake outlet is totally obstructed $\left(Q_{\text {out }}=0\right)$ when the cumulated iceberg height $\left(\mathrm{Jam}_{S}\right)$ is equal to the maximum value of the Weibull distribution of the iceberg heights $\left(\operatorname{Ice}_{h_{\max }}=\max \left(\operatorname{Ice}_{h}(\mathrm{t})\right)\right)$.

For the following jams, the increase of the critical channel depth due to the erosion of the channel bed during the iceberg jam flood has to be taken into account. It is modelled by the ratio $d_{c} / d_{c_{\text {init }}}$, where $\mathrm{d}_{c_{\text {init }}}$ is the initial value of $d_{c}$. As a consequence, after each release, the necessary jam size to totally obstruct the lake outlet also increases.

Then, the evolution of the critical channel depth of the lake outlet $\left(d_{c}\right)$ is modeled as a recursive function depending on water storage, jam size and an erosion coefficient $\mathrm{k}$ :

$$
d_{c}(t)=d_{c}(t-1)+k\left(\frac{W_{S}(t)}{W_{\text {Sinit }}}+\frac{\operatorname{Jam}_{S}(t)}{0.895 \times d_{c_{\text {init }}}}\right)
$$

The effects of water storage and jam size are both normalized relative to the first event water storage $\left(W_{s_{\text {init }}}\right)$ and $d_{c_{\text {init }}}$ respectively. In this study, $\mathrm{k}$ is equal to 0.001 .

The value of $\mathrm{dc}$ is updated after each iceberg jam flood event triggered by the release of the icebergs jam.

The release of the iceberg jam $\left(\operatorname{Jam}_{R}\right)$ is modeled as a logical function. For the present work, we assume that the jam is released when it totally obstructs the lake outlet and the water discharge $\left(Q_{\text {out }}\right)$ falls to zero:

$$
\operatorname{Jam}_{R}(t)=1 ; \text { if } Q_{\text {out }}(t)=0
$$

The peak discharge of the iceberg jam flood $\left(Q_{r}\right)$ is modeled as the sum of glacial meltwater discharge and the water stored until the jam release:

$$
Q_{r}(t)=Q_{i n}(t)+W_{s}(t) \times \operatorname{Jam}_{R}(t)
$$

For convenience, all the parameters are simulated in dimensionless units. The simulated data of iceberg jam floods $\left(Q_{r}\right)$ were used to quantitatively address the first two necessary conditions for SOC existence diagnosis. The simulation was carried out over a time period of more than one millennium ( $10 \times 10^{6}$ hours) in order to derive the two variables of magnitude and frequency of peak flows of iceberg jam floods required to test SOC.

The power-law between magnitude and frequency was statistically tested based on the cumulative frequency plot of the peak discharge of iceberg jam floods $\left(Q_{r}\right)$. Following the guidelines outlined in Clauset et al. (2009), the R package poweRlaw developed by Gillespie (2015) to fit heavy tailed distributions (as power law) with the maximum likelihood procedure was used. This software permits to determine the minimum value $\left(x_{\min }\right)$ for which power law behavior is appropriate. Kolmogorov-Smirnov goodness-of-fit tests were used to assess the quality of the fit, and the log normal alternative 
heavy tailed distributions was compared (Clauset et al., 2009; Gillespie, 2015).

\section{Results}

\subsection{The 2006 iceberg jam flood event in the Morsá river}

Downstream of the Morsárjökull glacier, the Morsá river flows out from a proglacial lake which was formed around 1945 (Roussel, 2008). The lake has remained connected to the glacier front since then. As a consequence, calving processes and iceberg drift have affected the proglacial fluvial system for several decades. During field work in the 2005, 2006 and 2007 summers, we observed repeated iceberg jam formation at the outlet of the proglacial lake. The connection between the proglacial lake and the outlet channel exhibits bathymetric thresholds that inhibit downstream evacuation of the biggest icebergs. They tend to accumulate at the outlet of the lake and form an iceberg jam which also traps smaller icebergs (fig. 3A-B). The bridge located downstream of the proglacial lake, which was present in summer 2005, was broken during an ice jam flood in late spring 2006 (personal communication of R.F. Kristjansson, Director of the Skaftafell National Park). During the summer 2006 field work, we noted the destruction of this marginal bridge and found fragments of the bridge more than 2 kilometers downstream on the sandur, testifying to the magnitude of iceberg jam floods (fig. 3C-E). The formation of iceberg jams was regularly observed on the proglacial lakes of the following glaciers during 2005, 2006 and 2007: Morsárjökull, Fjallsjökull, Breiðamerkurjökull, Fláajökull and Hoffellsjökull. Nevertheless, we did not observed the break-up of the iceberg dam in situ.

\subsection{Photo-observation of iceberg jam formation}

Using Google Earth ${ }^{\circledast}$ imagery and its time-lapse tool, the formation of iceberg jam was indirectly observed at the outlets of three icecontact lakes: Jökulsárlón, Fjallsárlón and a proglacial lake of Skeiðarárjökull (fig. 4). Well-formed ridges of accumulated icebergs can be observed on the aerial images of the Jökulsárlón and Fjallsárlón outlets (fig. 4A-D). The impact of the iceberg jam on the local water surface gradient can be clearly observed on the 20/09/2012 imagery through the transition from laminar to turbulent flow (fig. 4A-B). In contrast, iceberg jams at the outlet of the Skeiðarárjökull icecontact lake are much less densely aggregated (fig. 4E-F) and may have a lower effect on the local water surface gradient than a more cohesive iceberg jam. In more general terms, the degree of imbrication of the iceberg blocks might affect the effectiveness of the jam as a local control of the water flow gradient and energy.
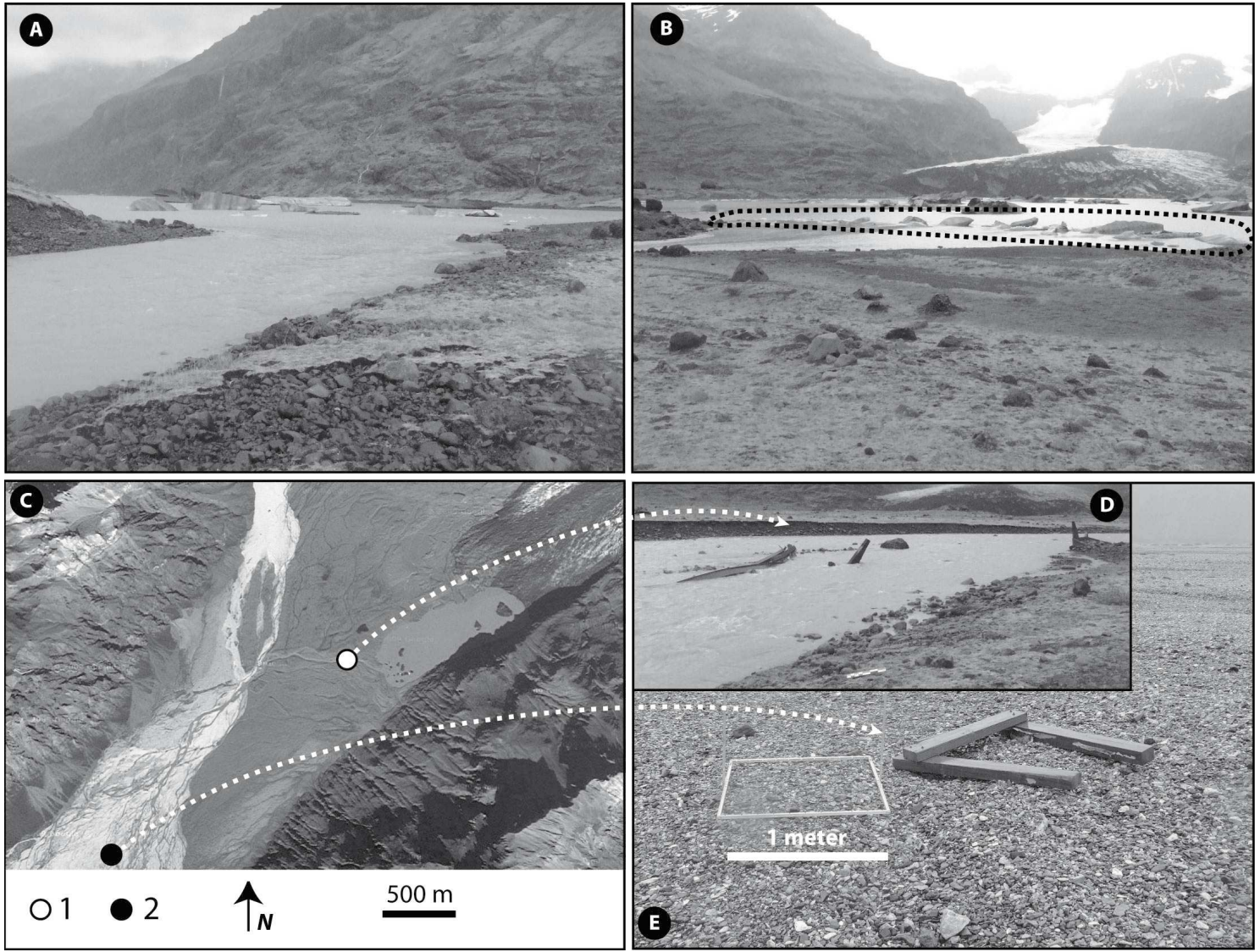

Fig. 3 - Formation of icebergs jam and impact of the 2006 iceberg jam flood downstream of the Morsárjökull proglacial lake.

A: icebergs accumulation at the outlet of the ice-contact lake. B: formation of the icebergs jam. C: Positions of the bridge destroyed during the 2006 iceberg jam flood. 1: pre-flood position of the bridge. 2: Position of bridge fragments found in July 2006 after the iceberg jam flood. E: Fragment of the bridge found on the active sandur in July 2006.

Fig. 3 - Constitution de barrages glaciels et impact de la crue limno-glacielle de 2006 en aval du la c proglaciaire du Morsárjökull.

A : Accumulation d'icebergs à l'exutoire du lac proglaciaire. B : Constitution du barrage glaciel. C: Positions du pont emporté lors de la crue limno-glacielle de 2006. 1 : Position du pont intact en 2005 et emporté au printemps 2006. 2 : Position du fragment de pont retrouvé sur le sandur en juillet 2006. D : Restes du pont emporté. E : Fragment du pont retrouvé sur le sandur en juillet 2006. 

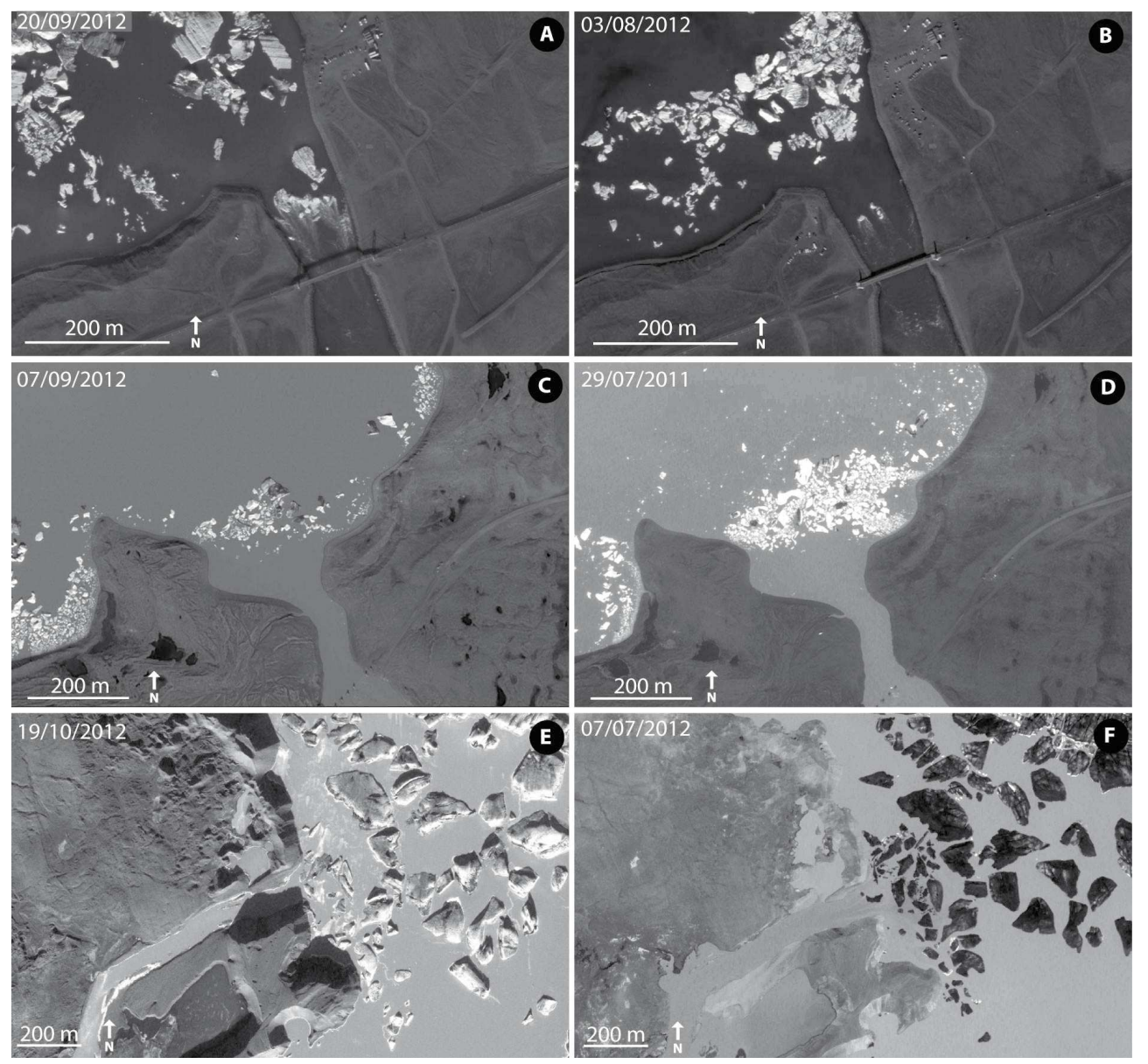

Fig. 4 - Photo-observation of icebergs jam formation using Google Earth imagery.

A, B: the jökulsárlón downstream of Breiðamerkurjökull. C, D: the Fjallsárlón downstream of the Fjallsjökull. E, F: Ice-contact lake downstream of the Skeiðarárjökull.

Tab. 1 - Quantification of the calving potential evolution of eleven proglacial areas in southeastern Iceland between 2003 and 2012.

L-2003: length of the glacier front in 2003; L-2012: length of the glacier front in 2012; ILL-2003: length of the ice/lake interface of the glacier front in 2003; ILL-2012: length of the ice/lake interface of the glacier front in 2012; LAKE-2003: ice-contact lake area in 2003; LAKE-2012: ice-contact lake area in 2012; ILP-2003: percentage of the glacier front with an ice/lake interface in 2003; ILP-2012: percentage of the glacier front with an ice/lake interface in 2012; ILP VARIATION: variation between 2003 and 2012 of the percentage of the glacier front with an ice/lake interface; LAKE VARIATION: variation between 2003 and 2012 of the ice-contact lake area.

Fig. 4 - Photo-observation de la formation de barrages glaciels à l'aide de Google Earth . $^{\oplus}$

A, B : le jökulsárlón en aval du Breiðamerkurjökull. C, D : le Fjallsárlón en aval du Fjallsjökull. E, F : lac proglaciaire en aval du Skeiðarárjökull.

Tab. 1 - Quantification de l'évolution du potentiel de vêlage de onze zones proglaciaires sud-islandaises entre 2003 et 2012.

L-2003 : longueur du front glaciaire en 2003 ; L-2012 : longueur du front glaciaire en 2012 ; ILL-2003 : longueur du front glaciaire présentant une interface glaciolacustre en 2003; ILL-2012 : longueur du front glaciaire présentant une interface glaciolacustre en 2012 ; LAKE-2003 : superficie du lac proglaciaire en 2003 ; LAKE-2012 : superficie $d u$ lac proglaciaire en 2012 ; ILP-2003 : pourcentage du front glaciaire présentant une interface glaciolacustre en 2003 ; ILP-2012 : pourcentage du front glaciaire présentant une interface glaciolacustre en 2012; ILP VARIATION : variation entre 2003 et 2012 $d u$ pourcentage $d u$ front glaciaire présentant une interface glaciolacustre ; LAKE VARIATION : variation entre 2003 et 2012 de la superficie du lac proglaciaire.

\begin{tabular}{|c|c|c|c|c|c|c|c|c|c|c|}
\hline GLACIER & $\begin{array}{c}\mathrm{L}-2003 \\
(\mathrm{Km})\end{array}$ & $\begin{array}{c}\mathrm{L}-2012 \\
(\mathrm{Km})\end{array}$ & $\begin{array}{c}\text { ILL-2003 } \\
(\mathrm{m})\end{array}$ & $\begin{array}{c}\text { ILL-2012 } \\
(\mathrm{m})\end{array}$ & $\begin{array}{c}\text { LAKE-2003 } \\
\left(\mathrm{km}^{2}\right)\end{array}$ & $\begin{array}{c}\text { LAKE-2012 } \\
\left(\mathrm{km}^{2}\right)\end{array}$ & $\begin{array}{c}\text { ILP-2003 } \\
(\%)\end{array}$ & $\begin{array}{c}\text { ILP-2012 } \\
(\%)\end{array}$ & $\begin{array}{c}\text { ILP VARIATION } \\
(\%)\end{array}$ & $\begin{array}{c}\text { LAKE VARIATION } \\
\left(\mathrm{Km}^{2}\right)\end{array}$ \\
\hline Morsárjökull & 1,28 & 1,73 & 520,60 & 497,18 & 0,33 & 0,41 & 40,72 & 28,69 & $-12,03$ & 0,08 \\
\hline Skaftafellsjökull & 2,93 & 3,93 & 1026,07 & 1982,90 & 0,23 & 0,39 & 35,03 & 50,50 & 15,47 & 0,16 \\
\hline Svínafellsjökull & 2,86 & 4,48 & 675,12 & 2599,93 & 0,08 & 0,18 & 23,59 & 58,04 & 34,46 & 0,10 \\
\hline Kvíárjökull & 4,43 & 5,11 & 754,61 & 2485,82 & 0,17 & 0,62 & 17,04 & 48,62 & 31,58 & 0,44 \\
\hline Fjallsjökull & 6,81 & 7,51 & 2363,57 & 3414,12 & 2,11 & 3,10 & 34,72 & 45,48 & 10,77 & 0,99 \\
\hline Breiðamerkurjökull & 20,17 & 18,76 & 7278,54 & 8544,91 & 22,82 & 30,53 & 36,09 & 45,54 & 9,44 & 7,71 \\
\hline Brókarjökull & 1,00 & 0,40 & 0 & 219,47 & 0 & 0,07 & 0 & 55,07 & 55,07 & 0,07 \\
\hline Skálafellsjökull & 2,68 & 3,25 & 621,64 & 717,45 & 0,11 & 0,20 & 23,18 & 22,06 & $-1,13$ & 0,09 \\
\hline Heinabergsjökull & 4,81 & 3,40 & 2869,97 & 3189,56 & 1,69 & 1,83 & 59,72 & 93,87 & 34,16 & 0,14 \\
\hline Fláajökull & 5,90 & 6,26 & 3094,77 & 1435,66 & 1,25 & 1,17 & 52,43 & 22,94 & $-29,49$ & $-0,08$ \\
\hline Hoffellsjökull & 4,31 & 4,61 & 4598,72 & 4691,34 & 0,50 & 0,49 & 106,67 & 101,80 & $-4,88$ & $-0,01$ \\
\hline Mean & 5,20 & 5,40 & 2163,96 & 2707,12 & 2,66 & 3,54 & 39,02 & 52,06 & 13,04 & 0,88 \\
\hline Standard-deviation & 5,28 & 4,84 & 2207,97 & 2366,05 & 6,72 & 9,00 & 27,79 & 25,81 & 24,49 & 2,29 \\
\hline
\end{tabular}




\subsection{Recent evolution of the calving potential in south-east Iceland}

The mapping of the glacier foreland on the Loftmyndir ${ }^{\circ}$, Google Earth $^{\circ}$ and Landsat imagery databases permits the quantification of the evolution between 2003 and 2012 of the area of ice-contact lake and the percentage of the glacier front with an ice/ lake interface (ILP). Considering the eleven glaciers investigated, the area of ice-contact lakes has increased by an average of $0.88 \mathrm{~km}^{2}$ between 2003 and 2012 (tab. 1). Nine of the eleven glaciers exhibit an increase of the ice-lake contact area between 2003 and 2012. The increase in lake area ranges between $0.07 \mathrm{~km}^{2}$ for Brókarjökull and $7.71 \mathrm{~km}^{2}$ for Breiðamerkurjökull. Only two ice-contact lakes had a minor decrease in size between 2003 and 2012, with a loss of 0.08 and $0.01 \mathrm{~km}^{2}$ for the Fláajökull and Hoffellsjökull lakes respectively. In front of Brókarjökull, an ice-contact lake was formed between 2003 and 2012.

The percentage of the glacier front with an ice/lake interface (ILP) increased by an average of $+13.04 \%$ between 2003 and 2012. Seven of the investigated glaciers show an increase of the percentage of the glacier front with an ice/lake interface which falls between $+9.44 \%$ for Breiðamerkurjökull and $+55.07 \%$ for Brókarjökull. Four glaciers exhibit a decrease of the ILP from $-1.13 \%$ for Skálafellsjökull and $-29.49 \%$ for Fláajökull. Overall, the calving potential of the glacier tongues of the south Vatnajökull has increased between 2003 and 2012. The probability of iceberg jam initiation and flood occurrence may have increased accordingly.

\subsection{Testing for SOC using a simple numerical model}

Based on the simulated data of iceberg jam floods $\left(Q_{r}\right)$ and the conceptualization of field observations of the jamming process, the four necessary conditions for SOC existence diagnosis are successively addressed.

(1) Non-linear temporal dynamics in the occurrence of ice jam flood: the first SOC condition of nonlinear temporal dynamics is demonstrated through the analysis of the variation of peak discharge of iceberg jam floods $\left(Q_{r}\right)$ with time (fig. $5 \mathrm{~A}$ ). The variation of peak discharges is highly erratic, even though the daily variation of meltwater $\left(Q_{i n}\right)$ and the iceberg calving stochastic law $\left(\right.$ Ice $\left._{h}\right)$ remain the same during the entire simulation. From one iceberg jam flood to the next event, the peak discharge can vary over three orders of magnitude. Thus, there is no significant linear correlation between meltwater discharge $\left(Q_{i n}\right)$, iceberg calving $\left(\right.$ Ice $\left._{h}\right)$ and peak discharges of iceberg jam floods $\left(Q_{r}\right)$. In other words, the nonlinearity in the temporal dynamic of the peak discharges of iceberg jam floods arises from the interactions of the meltwater and iceberg fluxes with the hydraulic properties of the lake outlet (i.e. the channel depth in this case).

(2) Inverse power-law relation between the magnitude and frequency of the iceberg jam flood: considering the entire distribution of the simulated peak discharges of iceberg jam floods, the magnitudefrequency plots exhibit a poorly significant inverse power-law relationship (fig. 5B). Indeed, the maximum likelihood procedure outlined by Clauset et al. (2009) and Gillespie (2015) yield a best fit power-law distribution $(\mathrm{p}$-value $=0.346$; goodness of fit $=0.0672$ ) commencing after the cut-off value $x_{\min }=521.1547$. In other words, only the extreme right tail of the peak discharges distribution (less than $10 \%$ of the highest simulated discharges) shows a significant power law behavior. The number of low-magnitude high-frequency floods is strongly too low to be described by the power-law. The alternative log normal heavy tailed distribution is clearly more appropriate to fit the peak discharges of iceberg jam floods $\left(p\right.$-value $=0.35 ; x_{\min }=138.98$; goodness of fit $=0.0212)$.

(3) The existence of a critical state of the system to which the system
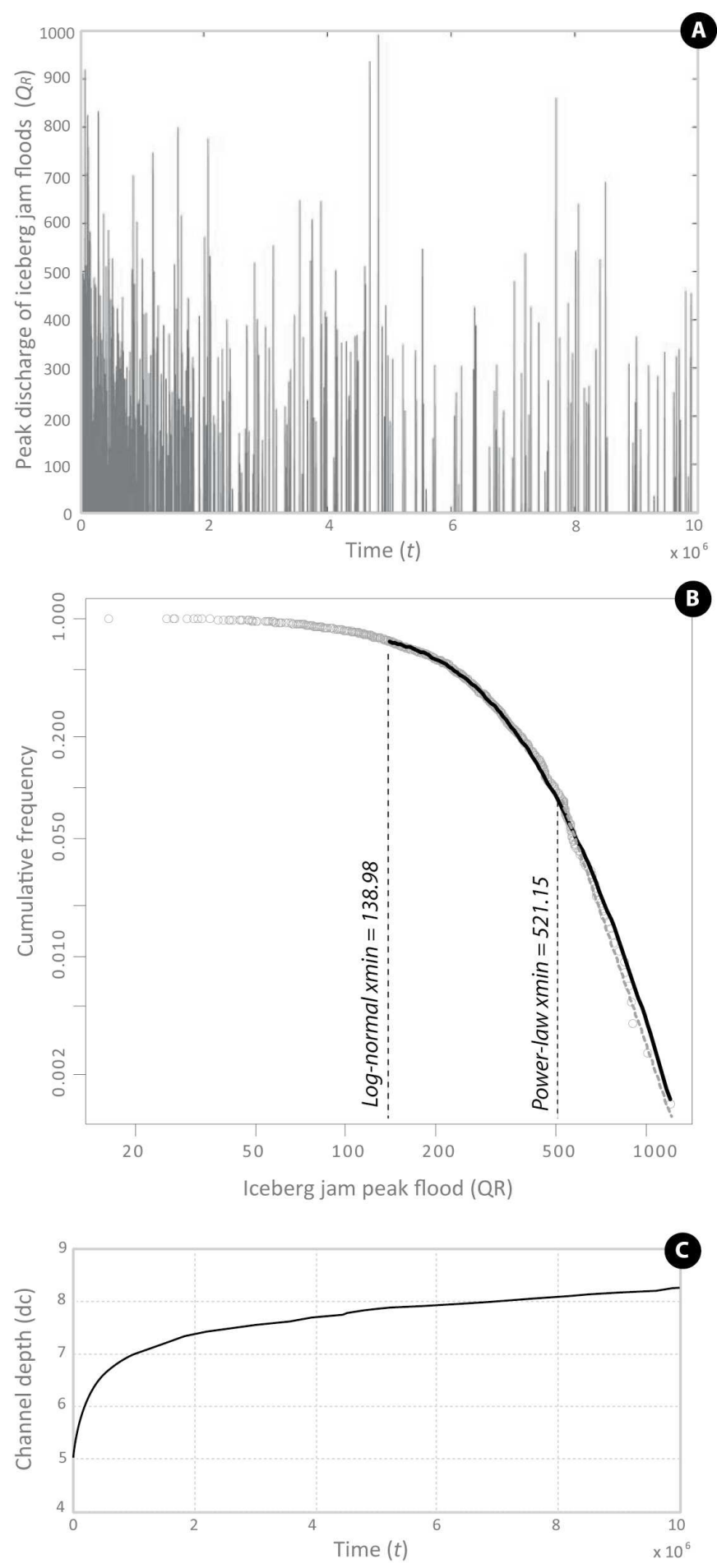

Fig. 5 - Results of the numerical simulation of iceberg jam floods.

A: Variation through time of the peak discharge of simulated iceberg jam floods $\left(Q_{r}\right)$; B: Cumulative frequency plot of the peak discharges of iceberg jam floods $\left(Q_{r}\right)$, the dotted grey curve is the best fit of power-law distribution commencing at the estimate of $\mathrm{X}_{\min }=521.15$, the black curve is the best fit of log-normal distribution commencing at the estimate of Xmin=138.98; C: Variation through time of the channel depth $\left(\mathrm{d}_{\mathrm{c}}\right)$ of the lake outlet.

Fig. 5 - Résultats de la simulation numérique des crues de barrage glaciel.

A : Variation temporelle des pics de débit des crues de barrage glaciel simulées $(Q)$;

$B$ : Courbe de fréquences cumulées des pics de débit des crues de barrage glaciel $\left(Q_{r}\right)$;

$C$ : Variation au cours du temps de la profondeur du chenal exutoire $\left(d_{c}\right)$. 

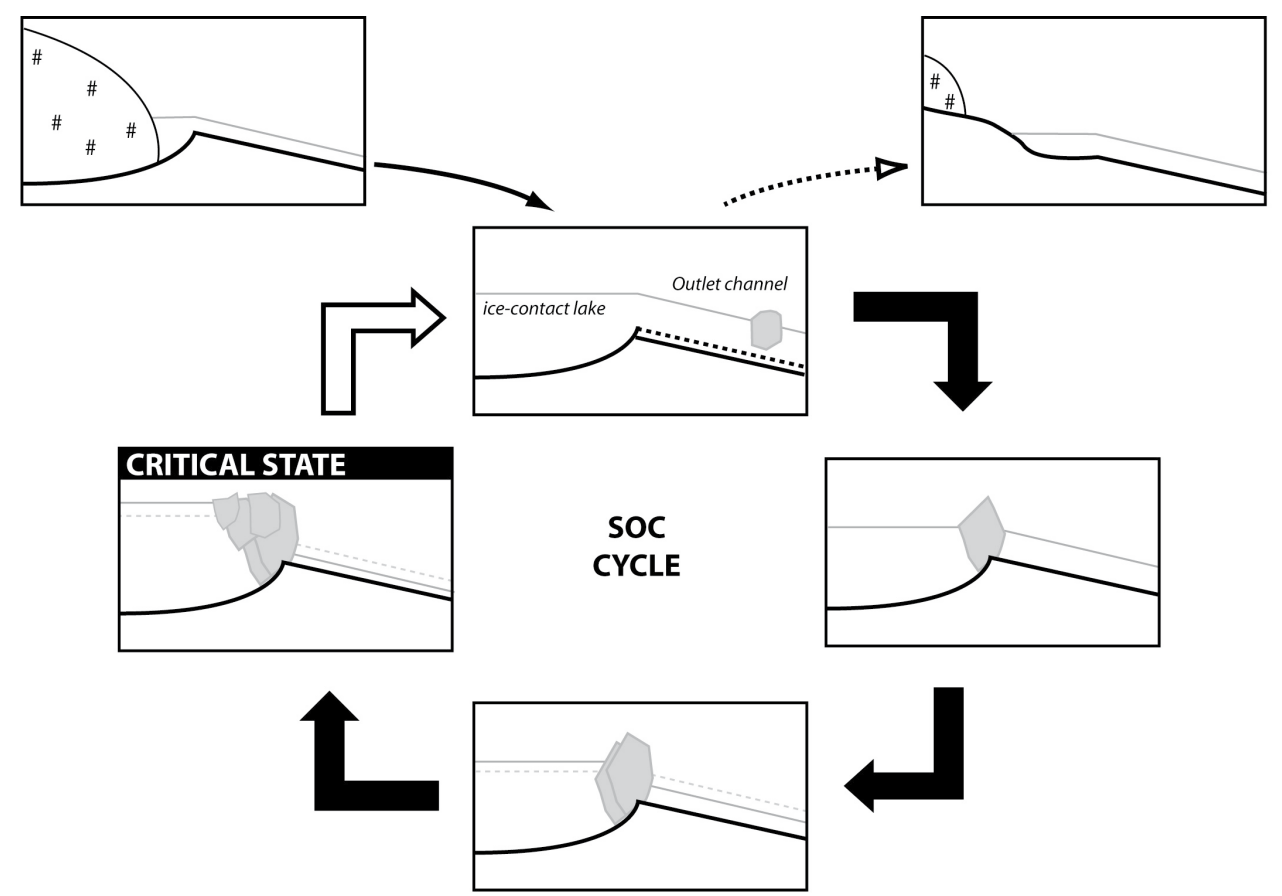

\section{$\# 1>2$ N $12 . .33$}

4

Fig. 6 - Conceptual m
jam flood recurrence.

1: glacier front; 2: bathymetry of the proglacial lake and the outlet channel; 3: progressive calibration of channel depth; 4: water surface level; 5: previous water surface level; 6: iceberg; 7: ice-contact lake creation (opening of the SOC cycle); 8: Stress accumulation; 9: stress relaxation and triggering of iceberg jam flood; 10: ending of SOC cycle.

readjusts after a disturbance: the recurrence of iceberg jam floods can be conceptualized as a cycle of self-organized criticality that affects the proglacial margin as soon as an ice-contact lake is created (fig. 6). The cycle of self-organized criticality starts with the gradual accumulation of stress though the initiation of an iceberg jam that hinders water flow and locally affects the water surface gradient. The local water surface gradient increases with the growth of the jam. As soon as the resistance threshold of the jam is exceeded, a flood is triggered and the stress is relaxed. Thus, the critical state can be defined as the slope of the water surface surrounding the iceberg jam and it therefore shows similarities with the so-called "angle of repose", the critical state of the classical sand-pile model (Bak et al., 1987). The threshold value of the water surface gradient, above which floods are triggered, depends on the buoyancy of the icebergs composing the jam and the hydraulic dimensions of the lake outlet. According to our simulations, the channel depth of the lake outlet $\left(d_{c}\right)$ is gradually enlarged by the succession of iceberg jam floods (fig. $5 \mathrm{C}$ ). Thus, the lake outlet becomes more and more efficient for evacuating the largest icebergs. It can lead to the end of the cycle of self-organized criticality if the channel depth exceeds the height of the largest icebergs produced at the glacier snout. The cycle of self-organized criticality can also be deactivated if the glacier margin becomes decoupled from the ice-marginal lake and calving ceases.

(4) The existence of a cascading mechanism by which the same process can initiate both low-magnitude and high-magnitude events: the simulated iceberg jam floods clearly show the occurrence of both high and low peak discharges initiated by the same process. This meets the criteria for a cycle of self-organized criticality as described above.

$6 \longrightarrow 7 ? 8 \quad \eta 9 \cdots \cdots+10$

Fig. 6 - Modèle conceptuel de létat critique et du cycle de criticalité autoorganisée associé aux crues de barrage glaciel.

1 : Front glaciaire ; 2 : Bathymétrie du lac proglaciaire et du chenal exutoire ; 3 : calibration progressive de la profondeur du chenal exutoire; 4 : ligne d'eau; 5 : niveau de la ligne d'eau antérieure; $6:$ iceberg; $7:$ Mise en place du lac proglaciaire (entrée dans le cycle de criticalité auto-organisée) ; 8 : Accumulation de la contrainte ; 9 : Relaxation de la contrainte et déclenchement des crues de barrage glaciel; 10 : Sortie du cycle de criticalité auto-organisée.

\subsection{Long-term trends in iceberg jam floods}

The time-series of the simulated iceberg jam floods has been divided into 40 periods of time (each period equal to 250000 units of time) in order to evaluate the long-term temporal trend in iceberg jam flood frequency, magnitude and variability (fig. 7). Based on the analysis of these 40 successive periods of time, the simulated data shows a significant decrease in the number of floods through time (fig. 7A). This decrease is well fitted by an inverse power function $\left(\mathrm{R}^{2}=0.90\right)$. This tendency is related to the gradual enlargement of the channel depth of the lake outlet which becomes increasingly efficient at exporting large icebergs. Consequently, the likelihood of iceberg jam formation tends to decrease through time. No significant trend in the magnitude of iceberg jam floods arises from the analysis of the variation of the mean of peak discharges through time (fig. 7B). Nevertheless, it should be observed that the variability of iceberg jam floods magnitude seems to decrease through time. Indeed, the standard deviation of peak discharges is well described by a negative linear regression (fig. 7C). In summary, as a consequence of the gradual enlargement of the hydraulic morphology of the lake outlet, the iceberg jam floods become less frequent and more similar in magnitude over time. 

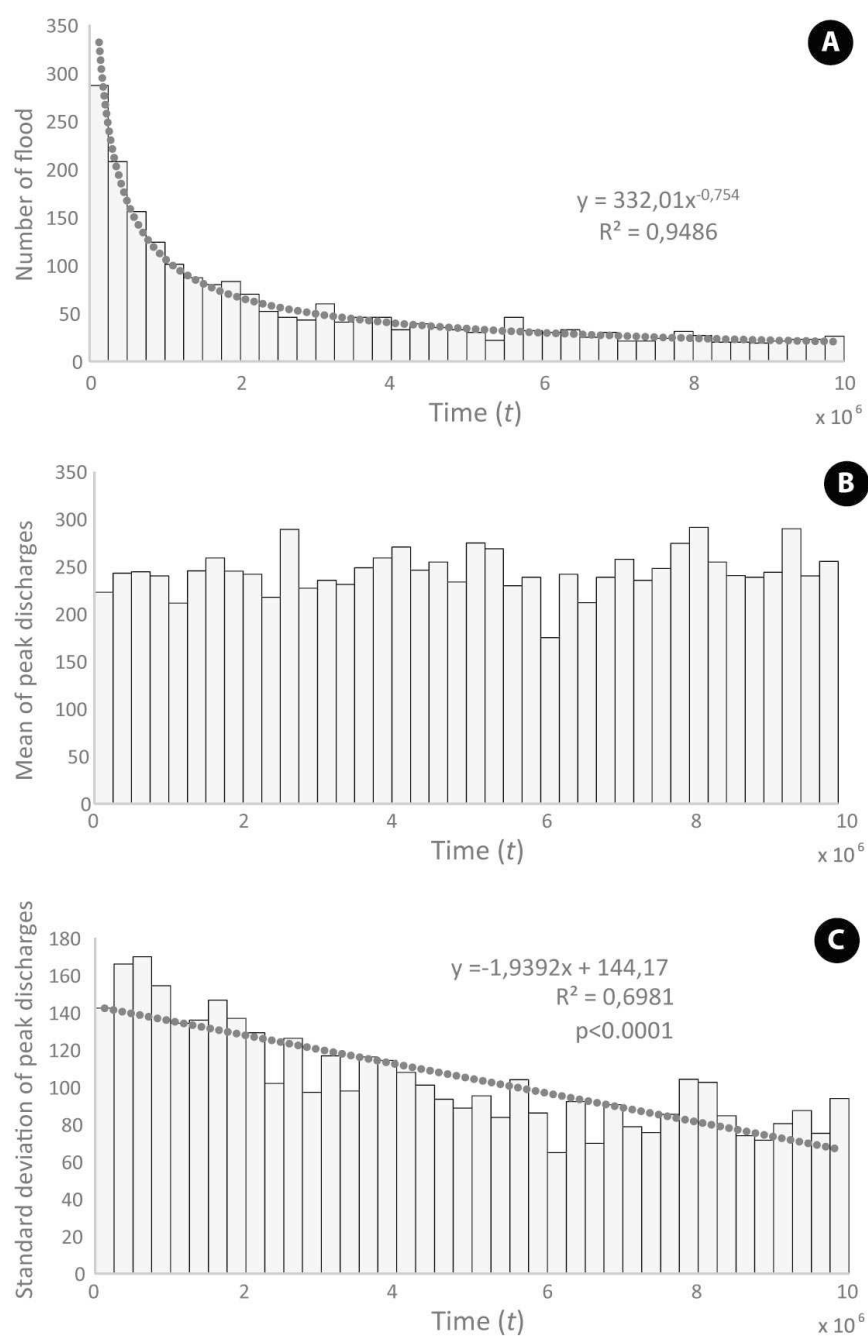

Fig. 7 - Analysis of the global temporal trends of the iceberg jam flood magnitude and frequency from numerical model results.

For the global analysis, time has been divided into 40 periods (each period equal to 250000 units of time). A: Variation of the number of floods through time; B: Variation of the mean of peak discharges through time; C: Variation of the standard deviation of peak discharges through time.

Fig. 7 - Analyses des tendances temporelles globales de la fréquence et magnitude des crues de barrage glaciel d'après les résultats du modèle numérique.

Pour les besoins de l'analyse globale, la variable temps a été divisé en 40 périodes (chacune équivalent à 250000 unité de temps). A : Variation du nombre de crue en fonction du temps; B: Variation de la moyenne du pic de débit en fonction du temps; $C$ : Variation de l'écart-type du pic de débit en fonction du temps.

\section{Discussion}

\subsection{Accepting or rejecting SOC}

The process of iceberg jam flood clearly meets three of the four criteria for self-organized criticality. The inverse power-law relation between the magnitude and frequency of the iceberg jam flood is the only condition that remains poorly verified. Indeed, the powerlaw overestimates the frequency of the simulated iceberg jam floods of low-magnitude. As it has been noticed in several studies (Bak et al., 1987; Turcotte, 1999; Van de Wiel and Coulthard, 2010; Croke et al., 2014), deviations from the inverse power-law are very common at the tails of the event distributions. It is especially the case for the left tail of the distribution which classically describes the low-magnitude high-frequency events. Indeed, the frequency of low magnitude events often falls below the predictions of the power-law due to the minimal size of the events allowed by the physics of the system studied (Turcotte, 1999). In our case, the initial depth value of the lake outlet and the minimal height of the icebergs inhibit the occurrence of flood events associated with lower values of channel depth and iceberg size.

As the deviation from the left tail of the inverse power-law is very common and that the three other conditions are verified, we suggest that iceberg jam floods should be recognized as a SOC phenomenon.

\subsection{Two successive SOC systems}

Åström et al. (2014) suggest that calving from the glacier margin is a SOC system. These icebergs then float across the lake and accumulate as a second SOC system that we are describing in this paper. An important question arises: does the SOC nature of iceberg jam flood arise from the SOC nature of the calving process or can these two processes be considered as two successive SOC systems? As the critical state of an iceberg jam flood resides in the slope of the water surface surrounding the iceberg jam, we suggest that iceberg jam floods should be considered as an autonomous SOC. Nevertheless the transition between the two SOC systems has not been documented in this study. Indeed, the implications of the mediation function of the lake on the iceberg size (i.e. melting of the icebergs during transit across the lake) and the jamming process have not been simulated. This question should be addressed in further work. Nevertheless, some likely consequences of the ice-contact lake on iceberg jam floods can be outlined. Clearly, the lake modulates the damming effects of ice-blocks that would collapse directly into the river. The smallest icebergs that would dam the river if they were collapsed directly into the river melt during the transition through the lake and become too small to initiate the jamming process at the lake outlet. As a result, low magnitude iceberg jam flood would be less frequent that expected from a SOC processes because of the mediation function of the lakes causing iceberg melting. We suggest that this modulating effect could compound the deviation of iceberg jam flood frequency from the left tail of the inverse power-law.

\subsection{Floods from ice-contact lakes: Other triggering factors}

It should be noticed that floods from ice-contact lakes may happen for other reasons than the internal process of iceberg jam release described in the SOC cycle of iceberg jam (Westoby et al., 2014; Worni et al., 2014). For instance, Marren and Toomath (2013) describe a flood triggered by an extreme rainfall event in 2006 causing the Skaftafellsjökull proglacial lake to overflow. The gravel layer deposited during this event is characterized by several ice-block obstacle marks which clearly testify that the flood of 2006 transported icebergs. Thus, external factors apart from the SOC cycle of iceberg jam flood, like rainstorms or jökulhlaups from subglacial lakes, are able to trigger floods with a magnitude efficient for icebergs exportation.

\subsection{Implications of iceberg jam floods for sediment fluxes}

Moraines and ice-contact lakes hinder sedimentary upstreamdownstream transport during the first decades of deglaciation and induce a decoupling between meltwater release and geomorphic activity. However, specific events such as iceberg jam floods may efficiently rework the outlet by enlarging and deepening the channels located across the confining moraine. More precisely, a three stage evolution of proglacial river can be as follows. During a first phase, the sediment and water discharges increase, favoring some exportation of sediments downstream. The frontal moraines are the primary 
sedimentary source, and are progressively eroded during these first years. This evolution can be slowed because of bed armouring of the outlet. Consequently, during a second phase, sediment storage occurs in the proglacial lake and the intra-morainic plain as the frontal moraine constitutes an efficient and stable base-level. The sediment discharge drops and the system thus remains blocked until the occurrence of a flood that breaks the armouring and restores the continuum. Given the stability of the moraines and the increasing size of the lakes, iceberg jam floods will become more common trigger during this phase. Then, during a third stage, sediment discharge may reach a maximum: sediments are first removed from the channel bed, while ongoing erosion encourages a reconnection of the intramoraine plain with the river.

Finally, sediment exportation sequences generally occur some decades after glacial retreat and are not necessarily coupled with the rate of glacial retreat and the amount of meltwater supply (Marren, 2002, 2005; Cossart, 2008; Cossart and Fort, 2008; Roussel, 2011). This pattern does not fit with the classical paraglacial model that implies a progressive decay of sediment exportation after glacial retreat. Nevertheless, the paraglacial period prepares the landscape through the build-up of sediment storage, while high magnitude events provide the capacity for sediment exportation. The role of such events (including all low frequency / high magnitude floods) has been hitherto underestimated. Even if SOC patterns are eventually averaged-out in sedimentation rates over one or several millennia (Church and Ryder, 1972; Jackson et al., 1982; Ritter and Ten-Brink, 1986), the SOC hypothesis implies that the geomorphic evolution of proglacial margins with moraine dammed lakes is sporadic over the timescales at which deglaciation generally occurs. It means that sediment exportation does not necessarily occur following a gradual trend of decay, but it is mostly driven by event-based tempo (such as iceberg jams dismantlement). Selforganized criticality is therefore an additional source of discharge variation in proglacial environments, and should be considered in evaluations of the magnitude-frequency regimes of proglacial rivers (e.g. Marren, 2005).

\section{Conclusion}

We described a marginal process associated with iceberg jams in proglacial lakes, and the ensuing floods. Based on field observations and aerial photo-interpretation, we demonstrated the occurrence of iceberg jams in ice-contact lakes in southeastern Iceland. The results of the mapping of the margins of the south Vatnajökull reveal an increase in the calving potential between 2003 and 2012. Thus, the probability of iceberg jam initiation and flood occurrence may have increased accordingly. In this study, we addressed the four necessary conditions for diagnosis of the existence of SOC in iceberg jam flood using a simple numerical model. As the deviation from the left tail of the inverse power-law (first criterion) is very common and that the three other SOC conditions are verified, we conclude that iceberg jam floods should be recognized as a SOC phenomenon. The analysis of the long-term trend of simulated flood series reveals that the iceberg jam floods become less frequent and more similar in magnitude over time as a consequence of the gradual enlargement of the lake outlet. Iceberg jam flood occurrence may have implications for the exportation of proglacial sediments and the geomorphic evolution of marginal fluvial systems. The low frequency high magnitude iceberg jam floods may be able to restore the sediment connectivity from the glacier front to the fluvial system by two processes: (1) the enlargement and deepening of the channels located across the confining moraine ridge; (2) the disruption of the bed armouring that commonly occurs in the channel that breaches the moraine dam.
Overall, the SOC nature of iceberg jam floods is an additional form of discharge variation, contributing to the highly sporadic sediment transport and geomorphic evolution of proglacial fluvial systems.

Improvements are needed in the surveying of iceberg jam floods in real settings. Further research should involve the monitoring of the triggering of iceberg jam floods (possibly using a fixed camera in the field) and the measurement of peak discharges (via a gauging station where possible). The numerical model also needs further refining to take into account the effect of the lake on the iceberg melting during transport, and the decrease in iceberg size. Finally, the effect of iceberg jam floods on the evolution of the sediment connectivity from the glacier to the fluvial systems has to be supported by real field measurements including the long-term monitoring of bedload transport (using a hydrophone for instance) at the lake outlet.

\section{Acknowledgements}

This work was supported by the GEOLAB-CNRS 6042, and the GDR "Mutations Polaires" (Coord. M. Griselin). The authors thank the Skaftafell National Park which provided assistance and accommodation, Pr. Marie-Françoise André for her help and support, and Yann Roussel for helpful discussions about the numerical model. The authors thank the two anonymous reviewers for their valuable comments and suggestions.

\section{References}

Åström J.A., Vallot D., Schäfer M., Welty E.Z., O’Neel S., Bartholomaus T.C., Liu Y., Riikilä T.I., Zwinger T., Timonen J., Moore J.C. (2014) - Termini of calving glaciers as self-organized critical systems. Nature Geoscience, 7, 874-878.

Bak P. (1996) - How Nature Works: The Science of Self-Organised Criticality. New York: Copernicus (Springer) $212 \mathrm{p}$.

Bak P., Tang C., Wiesenfeld K. (1987) - Self-organized criticality: An explanation of the $1 / \mathrm{f}$ noise. Physical Review Letters, 59, 381-384.

Bak P., Tang C., Wiesenfeld K. (1988) - Self-organised criticality. Physical Review A., 38 (1), 364-374.

Björnsson H., Pálsson F. (2008) - Icelandic glaciers. Jökull, 58, 365-386.

Ballantyne C.K., McCann S.B. (1980) - Short-lived damming of a high-arctic ice-marginal stream, Ellesmere Island, NWT, Canada. Journal of Glaciology, 25 (93), 487-491.

Boulton G.S. (1986) - Push moraines and glacier contact fans in marine and terrestrial environments. Sedimentology, 33, 677-698.

Carrivick J.L., Tweed F.S. (2013) - Proglacial lakes: character, behaviour and geological importance. Quaternary Science Reviews, 78, 34-52.

Chenet M., Roussel E., Jomelli V., Grancher D. (2010) Asynchronous Little Ice Age glacial maximum extent in southeast Iceland. Geomorphology, 114 (3), 253-260.

Chew L.C., Ashmore P.E. (2001) - Channel adjustment and a test of rational regime theory in a proglacial braided stream. Geomorphology, 37 (1-2), 43-63.

Church M., Ryder J.M. (1972) - Paraglacial sedimentation: a consideration of fluvial processes conditioned by glaciation. Geological Society of America Bulletin, 83, 3059-3072.

Clauset A., Shalizi C.R., Newman M.E.J. (2009) Power-law distributions in empirical data. SIAM Review, 51 (4), 661-703.

Cossart E., Fort M. (2008) - Sediment release and storage in early deglaciated areas: Towards an application of the exhaustion model from the case of Massif des Écrins (French Alps) since the Little Ice Age. Norsk Geografisk Tidsskrift - Norwegian Journal of Geography, 
$62(2), 115-131$

Cossart, E. (2014) - Des sources sédimentaires à l'exutoire : un problème de connectivité ? HDR, Université Blaise Pascal - Clermont 2.

Coulthard T.J., Van De Wiel M.J. (2007) - Quantifying fluvial non linearity and finding self organized criticality? Insights from simulations of river basin evolution. Geomorphology, 91 (3-4), 216-235.

Croke J., Denham R., Thompson C., Grove J. (2014) - Evidence of Self-Organized Criticality in riverbank mass failures: a matter of perspective? Earth Surface Processes and Landforms, 953-964.

Dhar D. (2006) - Theoretical studies of self-organized criticality. Physica A., 369, 29-70.

Fonstad M., Marcus W.A. (2003) - Self-Organized Criticality in Riverbank Systems. Annals of the Association of American Geographers, 93 (2), 281-296.

Frigg R. (2003) - Self-organised criticality - what it is and what it isn't. Studies in History and Philosophy of Science Part A., 34 (3), 613-632.

Gillespie C.S. (2015) - Fitting Heavy Tailed Distributions: The poweRlaw Package. Journal of Statistical Software, 64 (2), 1-16.

Gomez B., Page M., Bak P., Trustrum N. (2002) - Self-organized criticality in layered, lacustrine sediments formed by landsliding. Geology, 30 (6), 519-522.

Heckmann T., Schwanghart W. (2013) - Geomorphic coupling and sediment connectivity in an alpine catchment- Exploring sediment cascades using graph theory. Geomorphology, 182, 89-103.

Hergarten S., Neugebauer H.J. (1998) - Self-organized criticality in a landslide model. Geophysical Research Letters, 25 (6), 801-804.

Jackson L.E., MacDonald G.M., Wilson M.C. (1982) - Paraglacial origin for terraced river sediments in Bow Valley, Alberta. Canadian Journal of Earth Sciences, 19, 2219-2231.

Lu P., Li Z., Shi L., Huang W. (2013) - Marine radar observations of iceberg distribution in the summer Southern Ocean. Annals of Glaciology, 54 (62), 35-40.

Maizels J.K. (1979) - Proglacial aggradation and changes in braided channel patterns during period of glacier advance: an alpine example. Geografiska annaler, 61 (1-2), 87-101.

Marren P.M. (2002) - Glacier margin fluctuations, Skaftafellsjökull, Iceland: implications for sandur evolution. Boreas, 31 (1), 75-81.

Marren P.M. (2005) - Magnitude and frequency in proglacial rivers: a geomorphological and sedimentological perspective. Earth-Science Reviews, 70 (3-4), 203-251.

Marren P.M., Toomath S.C. (2013) - Fluvial adjustments in response to glacier retreat: Skaftafellsjökull, Iceland. Boreas, 42 (1), 57-70.

Marren P.M., Toomath S.C. (2014) - Channel pattern of proglacial rivers: topographic forcing due to glacier retreat. Earth Surface Processes and Landforms, 39 (7), 943-951.

Pelto M.S., Hedlund C. (2001) - Terminus behavior and response time of North Cascade glaciers, Washington, U.S.A. Journal of Glaciology, 47 (158), 497-506.

Peters I.R., Amundson J.M., Cassotto R., Fahnestock M., Darnell K.N., Truffer M., Zhang W.W. (2015) - Dynamic jamming of iceberg-choked fjords. Geophysical Research Letters, 42 (4), 2014GL062715.

Phillips JD. (1999) - Divergence, convergence, and self-organization in landscapes. Annals of the Association of American Geographers, 89 (3), 466-88

Phillips J.D. (1995) - Self-organization and landscape evolution. Progress in Physical Geography, 19 (3), 309-321.

Richardson S.D., Reynolds J.M. (2000) - An overview of glacial hazards in the Himalayas. Quaternary International, 65-66, 31-47.

Rigon R., Rinaldo A., Rodriguez-Iturbe I. (1994) - On landscape selforganization. Journal of Geophysical Research, 99 (B6), 11971-11993.

Rinaldo A., Rodriguez-Iturbe I., Rigon R., Ijjasz-Vasquez E., Bras R.L. (1993) - Self-Organized Fractal River Networks. Physical
Review Letters, 70 (6), 822-825

Ritter D.F., Ten Brink N.W. (1986) - Alluvial fan development and the glacial-glaciofluvial cycle. Nenana Valley, Alaska. Journal of Geology, 94, 613-615.

Roussel E. (2008) - Modification du style fluvial proglaciaire en contexte paraglaciaire: l'exemple du Morsárjökull. Bulletin de l'Association de géographes francais, 85 (2), 181-190.

Roussel E. (2011) - Réponses des glaciers et des sandurs sud-islandais au réchauffement climatique post-petit âge glaciaire: Modalités et rythmes dajustement du continuum glacio-fluvial. PHD Thesis, Université Blaise Pascal-Clermont-Ferrand II, $269 \mathrm{p}$.

Russell A.J., Van Tatenhove F.G., Van De Wal R.S. (1995) - Effects of ice-front collapse and flood generation on a proglacial river channel near kangerlussuaq (Søndre Strømfjord), west greenland. Hydrological processes, 9 (2), 213-226.

Schomacker A. (2010) - Expansion of ice-marginal lakes at the Vatnajökull ice cap, Iceland, from 1999 to 2009. Geomorphology, 119 (3-4), 232-236.

Turcotte D.L. (1999) - Self-organized criticality. Reports on progress in physics, 62 (10), 1377-1429.

Van De Wiel M.J., Coulthard T.J. (2010) - Self-organized criticality in river basins: Challenging sedimentary records of environmental change. Geology, 38 (1), 87-90.

Westoby M.J., Glasser N.F., Brasington J., Hambrey M.J., Quincey D.J., Reynolds J.M. (2014) - Modelling outburst floods from moraine-dammed glacial lakes. Earth-Science Reviews, 134, 137-159.

Worni R., Huggel C., Clague J.J., Schaub Y., Stoffel M. (2014) Coupling glacial lake impact, dam breach, and flood processes: A modeling perspective. Geomorphology, 224, 161-176.

\section{Version française abrégée}

En contexte de déglaciation, l'efficacité du transit hydrosédimentaire $d u$ glacier au système fluvial est conditionnée par la mise en place d'unités marginales de stockage (moraines, lacs proglaciaires, plaines intra-morainiques...). Les moraines frontales sont d'ailleurs identifiées comme des reliefs proglaciaires clés dans le contrôle de lexportation sédimentaire (Cossart, 2008 ; Roussel, 2011 ; Cossart, 2014) et l'ajustement géomorphologiques des cours deau marginaux (Marren et Toomath, 2013, 2014). Globalement, la structure paysagère fragmentée des marges proglaciaires est propice aux effets de barrage du transit hydrosédimentaire. L'émergence de lacs proglaciaires pérennes aggrave le découplage géomorphologique en capturant la charge sédimentaire grossière provenant du glacier, réduisant ainsi les flux sédimentaires $d u$ système fluvial (Chew and Ashmore, 2001; Marren, 2002 ; Marren and Toomath, 2013 ; Carrivick and Tweed, 2013). De plus, les icebergs issus $d u$ vêlage frontal traversent le lac proglaciaire et s'accumulent à l'exutoire du lac en formant un barrage glaciel. Ce barrage glaciel peut considérablement gêner lécoulement et affecte localement la pente de la ligne d'eau. Dès que le seuil de résistance du barrage glaciel est dépassé, une crue peut être déclenchée qui exporte l'eau stockée, une partie des icebergs formant le barrage et probablement des sédiments. Ainsi, la crue de barrage glaciel est un type dévénement fluvioglaciaire qui peut impacter les rivières proglaciaires au même titre que les jökulhlaups de barrages morainiques mieux connus (Westobyet al., 2014; Worni et al., 2014). Conceptuellement, le processus de formation du barrage glaciel et de déclenchement de la crue se rapproche des systèmes critiques auto-organisés (ou SOC, pour Self-Organized Criticality) définis par Bak et al. $(1987,1988)$. Les SOC peuvent être considérés comme un groupe de modèles formels qui décrivent un système dynamique qui se place spontanément dans une situation critique (criticalité auto-organisée) : des contraintes sont accumulées localement 
jusquà un point de rupture qui correspond au seuil critique de résistance du système à cette contrainte. La relaxation de la contrainte induit alors un phénomène de réaction en chaîne, appelé avalanche, qui se propage sur une échelle spatio-temporelle plus ou moins grande (Frigg, 2003). Une des propriétés remarquables des SOC réside dans la fonction puissance qui relie la magnitude et la fréquence des évènements de relaxation de la contrainte (Dahr, 2006). Les systèmes dynamiques présentant une tendance à la criticalité auto-organisée sont nombreux dans la nature : tremblements de terre, mouvements de masse, épidémies, feu de forêt (Turcotte, 1999; Bak, 1996). En géomorphologie, des approches modélisatrices fondées sur les concepts des SOC ont notamment été appliquées aux thématiques de lévolution paysagère sur le long terme (Rigon, 1994 ; Phillips, 1995), des mouvements de masses (Hergarten and Neugebauer, 1998 ; Gomez et al., 2002), du transport sédimentaire en contexte fluvial (Coulthard et Van de Wiel, 2007 ; Van de Wiel et Coulthard, 2010) ou d'érosion de berges (Fonstad and Marcus, 2003 ; Croke et al.,2014). Van de Wiel et Coulthard (2010) ont résumé les quatre conditions nécessaires pour diagnostiquer l'existence de SOC : (1) la dynamique temporelle non-linéaire de l'occurrence d'événements de perturbation dans le système; (2) une relation de loi de puissance inverse entre la magnitude et la fréquence des événements; (3) lexistence d'un état critique vers lequel le système se réajuste après une perturbation; (4) l'existence d'un mécanisme par lequel le même processus peut initier la fois des événements de faible et de haute magnitude. L'objectif de cette étude est double : (i) décrire le processus de formation des barrages glaciels sur la base d'observations de terrain et de photo-interprétations aériennes documentant l'occurrence de barrages glaciels dans les lacs proglaciaires du sud-est de l'slande; (ii) tester l'hypothèse selon laquelle les crues de barrage glaciel peuvent être assimilées à un SOC en utilisant notamment les résultats d'un modèle numérique simple de simulation des crues de barrage glaciel.

La zone détude est située dans la partie sud-est de l'Islande, autour de la région Öraefi de la calotte glaciaire du Vatnajökull (Figure 1A). Les zones proglaciaires de onze langues glaciaires ont été étudiées. Tous ces glaciers ont reculé depuis la fin du Petit Age Glaciaire (Chenet et al., 2010; Roussel, 2011).

Loccurrence de barrages glaciels a été documentée à partir d'observations de terrain (missions estivales en 2005, 2006 et 2007) et l'utilisation de la base de données images de Google Earth ${ }^{\circ}$. Sur la base de la photo-interprétation des images aériennes de 2003 de Loftmyndir et celles de 2012 de Google Earth ${ }^{\circledR}$ et Landsat, un travail de cartographie sous ArcGIS 10.1 a permis de quantifier lévolution du potentiel de vêlage et de la probabilité de formation de barrages glaciels en marge sud-est du Vatnajökull. Afin de tester la non-linéarité de la dynamique temporelle d'occurrence des crues de barrage glaciel et l'existence d'une relation puissance inverse entre amplitude et la fréquence, un modèle numérique simple a été bâti. Il simule la variation de neuf paramètres à travers le temps $(t)$ : le débit de fonte glaciaire $\left(Q_{i n}\right)$; le processus de vêlage et la hauteur des icebergs $\left(\right.$ Ice $_{h}$ ); la formation du barrage glaciel (Jam), sa taille (Jam) et sa libération $\left(\operatorname{Jam}_{R}\right)$; le stockage de l'eau en amont du barrage $\left(W_{s}\right)$; le débit liquide à la sortie du lac $\left(Q_{\text {out }}\right.$ et $Q_{r}$ ) et la profondeur du chenal à l'exutoire lac $\left(d_{c}\right)$. Afin d'illustrer les interactions entre ces paramètres, le modèle numérique a été schématisé graphiquement dans la figure 2.

Lors des missions de terrain sur les marges des langues glaciaires sudislandaises, nous avons observé la formation récurrente de barrages glaciels à l'exutoire des lacs proglaciaires du Morsárjökull (fig. 3A-B), du
Fjallsjökull, du Breiðamerkurjökull, du Fláajökull et de l'Hoffellsjökull. En particulier, les conséquences d'une crue de barrage glaciel survenue au printemps 2006 (communication personnelle de R.F. Kristjansson, Directeur du Parc National de Skaftafell) en aval du Morsárjökull ont pu être observées. Lors de la mission estivale de 2006, nous avons constaté la destruction du pont marginal et retrouvé un fragment des montants déposé à plus de 2 kilomètres en aval sur le sandur du Morsárjökull (fig. 3C-E). Ces éléments témoignent de l'intensité que peuvent atteindre ces types de crue. Sur la base des images Google Earth ${ }^{\circ}$, des barrages glaciels ont été observés à l'exutoire des lacs Jökulsárlón et Fjallsárlón (fig. 4A-D). L'impact du barrage glaciel sur la pente locale de la ligne d'eau, marquée par la transition de l'écoulement laminaire $\grave{a}$ turbulent, est clairement visible sur l'image datant $d u$ 20/09/2012 du Jökulsárlón (fig. 4A-B). Le travail de cartographie diachronique des marges sud du Vatnajökull mené à partir des images Loftmyndir ${ }^{\circledast}$, Google Earth ${ }^{\circledR}$ et Landsat montre une augmentation de la superficie des lacs proglaciaire de 0,88 $\mathrm{km}^{2}$ entre 2003 et 2012 (tab. 1). Dans le même temps, le pourcentage des fronts glaciaires avec une interface lacustre, donc potentiellement affectés par un processus de vêlage, a augmenté de $13,04 \%$. Ainsi, nos résultats montrent une augmentation significative de la potentialité de vêlage qui se traduit vraisemblablement par une hausse de la probabilité d'occurrence des crues de barrage glaciel. L'analyse des séries simulées de pics de crues de barrage glaciel permet de valider clairement trois des quatre critères permettant de diagnostiquer un processus SOC : la non-linéarité temporelle est attestée (fig. 5A), l'existence d'un état critique est révélée à travers la conceptualisation d'un cycle de criticalité auto-organisé (fig. 6) qui peut générer à la fois des crues de faible et de forte magnitude. Seul le critère de lexistence d'une relation de puissance inverse entre la magnitude et la fréquence des crues neest pas vérifié sur l'ensemble de nos données. Cette relation existe néanmoins de manière significative concernant les crues de magnitudes fortes (fig. 5B). Lanalyse des pics de crues simulées montre des tendances significatives sur le long terme. Nos résultats montrent que les crues de barrage glaciel deviennent moins fréquentes et d'intensité similaire au cours du temps (fig.7). Cette tendance globale est liée à la calibration progressive de la géométrie du chenal à l'exutoire du lac proglaciaire (fig. 5C).

Sur la base de résultats issus du modèle numérique et de nos observations de terrain, nous suggérons que les crues de barrage glaciel peuvent être considérées comme un phénomène caractérisé par la criticalité auto-organisé. Trois des quatre critères sont vérifiés et la déviation observée par rapport à la loi puissance inverse pour les évènements de faible magnitude est une propriété fréquemment rapporté dans la littérature concernant les SOC (Bak, 1987 ; Turcotte, 1999; Van de Wiel and Coulthard, 2010; Croke et al., 2014). L'existence de crues de barrage glaciel peut avoir de fortes conséquences sur le transit sédimentaire et lévolution géomorphologique des systèmes fluviaux marginaux. En effet, les crues de forte magnitude peuvent être en mesure de restaurer la connectivité sédimentaire du front du glacier au système fluvial par le biais de deux processus : (1) lélargissement et l'approfondissement des chenaux de franchissement des moraines frontales; (2) la destruction du pavage qui se produit généralement dans les chenaux de franchissement des barrages morainiques. Globalement, la criticalité auto-organisée qui affecte les crues de barrage glaciel contribue à renforcer le caractère sporadique du transit sédimentaire marginal et de lévolution géomorphologique des systèmes fluviaux proglaciaires. 